\title{
The Reception of Harold Pinter's Plays in Slovenia between 1999 and 2014
}

\begin{abstract}
Harold Pinter started his career with a conspicuous lack of success. He faced negative critical reviews of his early works, but his typical style eventually opened doors to new worlds in modern drama. On Slovene stages, Pinter's plays also received a similarly modest welcome. The audience as well as the reviewers found his long pauses, silences and incoherent dialogue insufficiently engaging. One of the main reasons for this could have been their unfamiliarity with Pinter's style, which eventually acquired its own adjective - 'Pinteresque'. With time, Pinter's popularity increased more rapidly on the world stages than in Slovenia, and today this playwright is not a stranger to the Slovene theatre. This article deals with Pinter on Slovene stages as well as the popular and critical reception of his plays. The period before 1999 was thoroughly analysed by Darja Hribar, while this study is the first to focus on the decade and a half following.
\end{abstract}

Keywords: Harold Pinter; drama; theatre; reception; translation

\section{Recepcija dram Harolda Pinterja v Sloveniji med letoma 1999 in 2014}

\section{POVZETEK}

Harold Pinter je svojo gledališko kariero začel dokaj skromno. Pri uprizoritvah nekaterih svojih zgodnjih del se je spopadel s številnimi negativnimi kritikami, a sčasoma je njegov slog odprl vrata novim svetovom v moderni dramatiki. Tudi na Slovenskem so Pinterjeva dela doživela zadržano dobrodošlico. Tako občinstvu kot kritiki se njegove značilne dolge pavze ter nepovezani dialogi niso zdeli dovolj zanimivi. Med glavne razloge za takšen odziv lahko štejemo Pinterjev nov način dramskega izraza, katerega specifike so sčasoma pridobile oznako 'pinterjanski' oz. 'pinterjevski'. V svetu je avtorjeva prepoznavnost naraščala hitreje kot na Slovenskem, vendar danes dramatik slovenskemu gledališču ni več tuj. Članek se ukvarja s Pinterjem na slovenski dramski sceni ter z odzivi kritike in občinstva nanje. Obdobje do leta 1999 je v tem pogledu temeljito raziskala Darja Hribar, ta raziskava pa se posveča desetletju in pol, ki temu obdobju sledi.

Ključne besede: Harold Pinter; drama; gledališče; sprejemanje; prevod 


\section{The Reception of Harold Pinter's Plays in Slovenia between 1999 and 2014}

\section{Introduction}

According to Peter Raby $(2009,1)$, statistical data shows that, in the present international world of drama, Pinter is one of its best known as well as most widely performed playwrights. His public activity is by no means limited to drama and theatre. Rather, "the horizon of his literary, cultural and political projects stretches far beyond the borders of his homeland, as well as beyond theatrical and literary world" (Onič 2012, 5). Richard Cave agrees with this and even reaches beyond this statement by adding that "one is astonished at the sheer range and variety of endeavour to which [Pinter] has brought a focused and profound commitment" $(2009,123)$.

Apart from his literary heritage, Pinter is most widely known for his activism in defending the human rights of politically oppressed nations and individuals. He frequently stated his world views through his work - articles and letters, poems, plays and radio plays (Derbyshire 2009, 269). Andrew Goodspeed explains that Pinter significantly objected to the "falsity of politicians' analyses and justification of the pain their policies inflict" $(2012,54)$ and that his political beliefs and criticism had appeared continuously in his previous public speeches or interviews; however, his Nobel lecture in 2005 gave him a wider international audience than the usual limited crowd. Therefore, comments suggesting that Pinter had won the award for his political activity and not for his artistic contribution are not surprising (Onič 2007, 117).

Fairly early in Pinter's career, his literary and theatrical excellence as well as his political impact started to move beyond the English-speaking world. His plays first appeared in Slovene theatres in the late 1960s and early 1970s. Initially, critical material and literary research results on this topic were scarce, but the situation has changed recently. Darja Hribar (1999) conducted the first major study of the Slovene translations of Pinter's plays and collected a body of critical reviews referring either to the original plays or to their Slovene theatre productions, thus initiating Pinter Studies in Slovenia. This article gathers the results of a similar research that focused on the theatre productions of Pinter's plays and critical response to them during the 15-year period following Hribar's study.

\section{Pinter on Slovene Stages before 1999}

Harold Pinter wrote his first play, The Room, in 1957, and it was staged in London in the same year. Slovenia got its first production of a Pinter play a decade later with The Homecoming in 1967, and Slovene theatres have continued to stage Pinter ever since. Altogether, there were 13 productions of 6 Pinter's plays in Slovenia before the turn to the 21st century. These were Homecoming, The Caretaker, Old Times, The Birthday Party, Betrayal and Ashes to Ashes.

The plays Old Times (Njega dni, 1974 / Stari časi, 1982, 1987) and The Birthday Party (Zabava za rojstni dan, 1979, 1991, 1997) were produced three times each. Moreover, the 1979 staging of the latter saw 43 performances, which is the highest number of any single Pinter production on a Slovene stage to date. The next play on the list of repetitions per production is Homecoming (Vrnitev, 1967), with 37 performances, another result that has never been repeated since. The only number of performances in a single theatrical season that surpasses both previously stated figures is 68, which is the number of repetitions of the two 1979 productions of The 
Birthday Party and Betrayal (Prevara) together. If we compare these figures to those of either traditionally more popular genres (various comedies, etc.) or plays by the then more established playwrights that could receive three or four times as many repetitions, we must agree with Onič (2008b) that Pinter cannot be considered popular with a wide theatre audience of the time. On the other hand, theatre practitioners, who are still today challenged by Pinter's texts, have tended to return to them. Good examples of this are Zvone Šedlbauer, who directed four productions of Pinter in Slovenia, and Miran Herzog, who directed two. In terms of the number of performances, Betrayal comes first with 50 performances altogether. Šedlbauer's 1995 production even ran for two seasons. The only other production achieving this number was Ashes to Ashes (V prah se povrnes') in 1998. It must be noted that some data regarding early performances are not available.

Based on the Slovene theatre production of Pinter's plays before 1999 (Hribar 1999), ${ }^{1}$ one can conclude that the playwright was a breath of fresh air for Slovene repertories. The audience's expectations as well as their curiosity were high, the actors and directors were inspired, but most reviewers felt confused. The first Pinter play staged in Slovenia, Homecoming, premiered on 27 October 1967. The reviewer(s) looked for comical aspects of the play and wondered at the reasons for Pinter's writing the piece. Much praise was given to the acting team by all reviewers, but the play itself was marked as an "unnecessary part of the repertory"2 (Vidmar, 1967; cited in Hribar 1999, 206-7), which suggests that even renowned critics like Josip Vidmar failed to recognize the value and power of Pinter's text. Some tried to determine the meaning of the play by comparing "human intellect with human primitivism" (Novak, 1967; cited in Hribar 1999, 207) or "finding the truth of human rhapsodically inspired life and non-symphonically regulated existence" (Predan, 1967; cited in Hribar 1999, 208). We can see from these quotations that the reviewers tried to comment on the meaning of the play and sought its comic perspective. This shows the lack of understanding of the playwright's style as well as the adopted misconception that his plays are traditional plot-oriented pieces.

The situation changed slightly with the second Pinter play staged in Slovenia, which was The Caretaker. ${ }^{3}$ The theatre programme for its 1970 production offered an extensive study on the playwright and his style. Obviously, the intention was to bring both closer to the public, yet there were still no openly supportive reviews of the performances. Similarly to the response to Homecoming, which had been reviewed as unnecessary and not at all enriching for the repertory, one of the reactions to The Caretaker was that the "director could have, without causing any harm, shortened that typical but tiring repetition of certain phrases" (Onič 2004, 92; see Javornik 1970, 10). According to Hribar (1999, 212-14), the first positive reviews followed the Slovene premiere of Old Times in 1974, which was labelled as a piece of a new dramatic style. In addition, many typical Pinteresque elements were recognized and highlighted in the reviews. Pinter's psychological word play was recognized, and his mastery of interfering with subtextual speech was praised.

The majority of data in this section of the article were acquired from Hribar's doctoral dissertation (1999). She commented on the performances of Pinter in Slovenia to 1999 and analysed the reviewer's response. In the same year, Mirko Mrčela (1999) completed a Master's Thesis on the reception of Pinter in Slovenia. Early productions of Pinter in Slovenia were also dealt with by Tomaž Onič in one of the chapters in the monograph Harold Pinter on the International Stages $(2014,77-87)$.

2 Unless otherwise specified, all excerpts from the Slovene reviews of Pinter's plays in this article are translated by the author of this article.

3 For a complete insight into the two Slovene productions of The Caretaker, see Onič (2004). 
The Birthday Party, which premiered in Ljubljana in 1979, was presented as timeless and independent of any specific setting. As Hribar (1999, 219) reports, the reviewers were still trying to present and explain Pinter's stylistic features to the audience to get a better response from the audience. For example, they interpreted Pinter's dialogue, explained the relevance of information, the allegorical message and the grotesque features. The reviews were increasingly positive, or at least not too harsh. The actors were still getting more praise than the author, but the attention gradually shifted to the characteristics of Pinter's writing style, and the reviewers began to compare it to Beckett and Ionesco, usually referring to its absurdist features (Hribar 1999, 220). One of the first reviewers to use Pinter's name as an adjective 'pinterjevska' to describe the production of a play was Dimitrij Rupel, whose review appeared in Teleks (cited in Hribar 1999, 219). Betrayal was premiered in the same year, and the reviewer pointed out that much attention was given to the existential relationships between the characters through the typical Pinter dialogue. Silence was recognized as a tool of communication, and Pinter was again compared to Beckett and also to Kafka (Hribar 1999, 220).

The 1982 Old Times was a student production at the Academy of Theatre, Radio, Film and Television. Hribar mentions a review by Franc Vurnik focusing on Pinter's ability to present an ordinary relationship from a different point of view: "Caught in their memories, Pinter's characters somehow always seem to end up in a never ending circle of solitude" (cited in Hribar 1999, 220-21). The reviewers were clearly starting to focus more on Pinter's style and not so much on the performance. The third Slovene production of Old Times introduced a new Slovene version of the adjective Pinteresque, i.e., 'pinterjansko'.4 Although most of the reviewers found Pinter's plays fascinating, and some even called him "a master of playwriting", some still commented that Pinter's plays did not deserve a place on stage, since they could have worked just as well on the radio (Hribar 1999, 222). The dialogues and monologues were critiqued as being boring and too long (Lah 1987, cited in Hribar 1999, 222).

At the time of the 1990 production of The Caretaker, the London theatre audience was trying to see Pinter's plays from the political angle. Because of his involvement in political activism, his plays were no longer compared only to Beckett and Kafka; but Michael Billington in The Guardian (1994) also compares him to other artists like Michael Miles or Jack Benny (cited in Hribar 1999, 222-23). After The Birthday Party in 1991 and Betrayal in 1995, the reviews of the 1997 Homecoming took a slight turn towards suggesting how the play should have been understood, highlighting what a difficult task it was for the actors and producers to "capture the intended atmosphere" (Pezdir, 1997; cited in Hribar 1999, 227). The actors were praised for doing a wonderful job (Jež, 1997 cited in Hribar 1999, 227), and better reception of the play was attributed to a more mature society, which had, however, still not done away with the taboos "to the extent to make prostitutes, grotesque family relationships and scary unexpected characters part of their acceptable vision of everyday life" (Šuklje, 1997; cited in Hribar 1999, 228). Notably, the reviewers found that the dated translation influenced the quality of the play.

The Birthday Party produced in 1997 was labelled comedy of menace, ${ }^{5}$ and the theatre programme dealt extensively with salient characteristics of Pinter's discourse. It praised the playwright's ability

\footnotetext{
There is probably no particular reason for the varied adjective. The Slovene word formation allows pinterjanski and pinterjevski, as well as the calque pinteresken.

The expression was coined by Irving Wardle $(1958,28)$, referring to a rather unusual amalgamation of the comical and the seriously threatening in drama. Although not originally created with Pinter's plays in mind, the concept was more and more frequently used to denote his early plays, most notably The Caretaker, The Dumb Waiter and The Birthday Party.
} 
to use the power of words to create tension, mood and mystery in the play. Pauses and silences earned a place in the positively oriented review by Primož Jesenko (Hribar 1999, 228-29). The response to Ashes to Ashes in 1998 was similarly appreciative of the play and explanatory in terms of possible interpretations. This was the last Pinter produced in Slovenia before the turn to the 21 st century.

\section{Pinter on Slovene Stages after 1999}

There were fourteen productions of Pinter plays on Slovene stages in the period from 1999 to 2014, which is one more than in the period from 1967 to 1999. A quick comparison suggests that, with almost the same number of premieres in both periods, where the earlier period is more than twice as long as the one after 1999, the frequency of performances has more than doubled in the last decade and a half. This may have to do with the fact that Pinter became an established author, and staging his plays was no longer an experiment, let alone a risk. Apart from his literary activity and a series of prestigious literary awards - some of which came just before the turn of the century - his political engagement contributed to his growing fame. Let us now proceed to particular productions and a selection of critical reviews.

The most frequently staged play after 1999 was The Dumb Waiter, which saw five different productions. This play is also the one with the most variants of title translations within this time frame: Futrlift, Strežni jašek, Jašek and Mutasti natakar, which in back-translation mean, respectively, fodderlift (fodder as animal food; both parts of the compound are dialectal/substandard language use and so is the entire translation ${ }^{6}$ ), serving shaft (meaning food elevator connecting dining room and kitchen when they are on different floors), shaft (similar to the previous meaning but less specific, so without the concept of serving attached to it, it hints at a mining shaft or a drain shaft, which allows rich interpretations), and dumb waiter (literal meaning with no reference to food elevator but alluding to several possible readings of the original; a detailed explanation of this translation problem is given by Onič (2011b) in the theatre programme for the 2011 Ptuj production). In terms of the number of productions, The Dumb Waiter is followed by The Birthday Party and Celebration, each of which was staged twice.

The reviewers of the 2000 production of The Dumb Waiter mainly focused on description of and commentary on Pinter's style and on the theatre of the absurd, assuming that the audience would still be unfamiliar with it. Therefore, the reviews included other representative authors of the absurdist movement and set out to popularize the genre of the comedy of menace. The reader cannot avoid the impression that, in a way, the reviewers wanted to comfort the audience and reassure them that the play was supposed to be understood in the way they experienced it; "the performance managed to present Pinter's typical scary and mysterious atmosphere with the hint of humour" (Svetej 2001, 20).

In 2001, The Lover was staged in Ljubljana. The reviewers praised the actors and their acting skills, while, surprisingly, modest praise was given to the playwright. It is possible that applauding Pinter might seem, to them, to be stating the obvious and thus unnecessary. The reviewers seemed obliged to convey their own interpretation of the play or parts of it in the review as an explanation of the complex interpersonal relationships: "[I] maginary lover functions as a symptom of the corroded couple's relationship" (Jesenko 2001, 11). Moreover, a comment by the same reviewer suggests a mysterious hidden meaning for the play: "The play [...] gives the

On specifics of dialect in drama translation, see Onič (2008a). 
impression of an analytical, disciplined in terms of acting, and Pinteresquely bizarre commentary on the stability of the respectable bourgeois marriage, protected by seemingly strong walls" (Jesenko 2001, 11). With this comment, Jesenko points out that everyone has some skeletons in the closet and includes his perception of that observation.

With the production of The Birthday Party in 2002, we witnessed a significant turn in the reviews. The reviewers tended not to dabble in interpretation of the play. They started allowing the mystery of the 'Pinteresque' to speak for itself, encouraging the audience to create their own interpretations. This particular production of The Birthday Party was recognized as a modern classic, since it was placed in modern times, and also as a "well-thought-over mix of genres, atmospheres and relationships" (Jurca Tadel 2003, 265). The reviews suggested that the play was not simple and transparent, but interesting enough for those seeking a theatrical thrill. The readers of the reviews were faced with the options of finding the mystery in the comedy of menace either challenging or too complicated. This production of The Birthday Party had 20 performances, was seen by 3674 playgoers, and also received an award at the most important Slovene theatre event, The Borštnik Festival.

We noticed that a significant rise in publicity accompanied the 2003 production of Celebration. This was a new play by Pinter written in 1999, and some reviewers expressed doubt whether it would live up to expectations; these were probably higher, since Pinter was no longer an obscure author, and the audience already had a certain knowledge of his style. However, all the reviewers commented that Pinter's plays were still as good as forty years ago. The production was a success; it was performed 25 times and seen by 5592 playgoers. The reviewers still commented on Pinter's style, but not in an ambiguous way. His plays in general were acknowledged as quality pieces of theatre, and, in the case of Celebration, it was the performance that was scrutinized and reported as lacking in quality. The reviewers also praised the high quality translation by Alja Predan, which respected and preserved much of Pinter's style, and recognized this fact as significant in securing a good production.

In terms of Pinter on stage, 2004 was a prolific year. Slovenia saw three productions: Remembrance of Things Past, The Dumb Waiter and The Birthday Party. The recognition of Pinter and his style remained unquestioned. He was again noted as a representative of the theatre of the absurd and was often compared to Beckett and Ionesco. The reviewers brought forward the details that could be identified as the 'Pinteresque' essence of the production (or the lack of it, for that matter): "[S]ome scenes were just not scary enough, and towards the end the tension started to drop" (Golob 2004, 11). The evolution of the public response continued in 2006 when the reviews began to embrace the fact that Pinter's plays are applicable at any time and any place, since two performances of The Dumb Waiter were set in the present. The producers and reviewers started to appreciate the depth and the variety of dimensions of Pinter. Marjana Ravnjak commented that the play was a "successful presentation of the present relationship between society and politics, and a constant struggle of lie versus truth, and art versus life in the intense performance" (2006).

The reviewers of the 2008 production of Homecoming observed how 'Pinteresque' elements of the performance influenced the audience: "The absence of actors' feelings was interesting for the audience" (Jurca Tadel 2008, 305). The latter seemed ready to accept Pinter's plays as amusing and entertaining, not only challenging. The production was rated highly, lasting through 16 performances. In the public response it was observed that individual interpretation becomes important, which, along with the choice of scenery, acting skills and other elements also highlights the value of high quality translation. All new translations were duly noted, and 
their effect in each production was analysed. Moreover, as observed in the response to Pinter's plays in the following years, the reviewers started to expect performances to thoroughly express the specifics of Pinter's style. For example, in commenting on The Dumb Waiter in 2011, Rak found that the performance lacked the "magnetic field to create the 'Pinteresque' absence of sense" $(2011 \mathrm{a}, 15)$. Reviews were more focused on the directing and sought the reasons for what could be seen as flaws in the performance within the production and not in the original text of the play. For instance, the cultural difference seemed to remain an obstacle when presenting British humour. Rak (2011a, 15) believed that it was impossible to put such a typical British play with British characteristics on a Slovene stage and integrate it into Slovene culture, despite the promising new translation. The reviewers also identified producers who favoured Pinter's plays and had picked up on Pinter's attitude when staging his plays. Rak, for example, comments on the director/producer who staged Old Times in 2011: "[Peter] Boštjančič and Pinter have one thing in common: they do not care about what other people think. [...] Boštjančič is only interested in those 20 or 30 people who take the time in the evening to see Old Times" (Rak, $2011 \mathrm{~b}, 16)$. Moreover, this reviewer has no problem declaring a performance successful even if it does not attract a huge audience and also claims this as a major step forward in Slovene reception of and response to Harold Pinter. Pinter's plays are not aimed at the masses, so a small, solid audience is a reliable indication of good reception.

The importance of quality directing is brought to our attention in the reviews of the production of Betrayal that was staged in 2011. The production had no official director, and that was the main reproach noted among the reviewers. Tadel stated that "being without a director caused some flaws in interpretation; although the team included only good actors" (Tadel 2011, 27). It is also likely that the reviewers commented on this, because staging a play without a director is more the exception than common practice on the Slovene theatre scene.

The production of Celebration in Kranj in 2013 received great publicity. In addition to praising Pinter, reviewers observed that the performance succeeded in leaving the audience with more questions than answers, and that it implemented other expected elements of Pinter's style. Additionally, they found the play amusing and educational at the same time, including humorous inserts. Štaudohar comments that this play was a "reflection of real life attracting the viewers in a very interesting way: by saying that by attending this performance you will find out that you are not the only one with a screwed up life" (2013). The awareness that we are still able to identify with the relationships and situations on stage, even though decades have passed since these plays were written, suggests that they are timeless.

Although Pinter's masterpieces eventually spoke for themselves and made him famous, this study found that several factors influenced the popularity and reception of Pinter and his work in Slovenia. Undoubtedly, among these factors are the Nobel Prize in Literature in 2005 and his death in 2008. Judging by the number of Pinter plays produced in Slovenia shortly after those two events, we were unable to prove their influence at first. It was anticipated that these two events would have caused an increase in producing Pinter's plays after 2005 and after 2008, nevertheless; the final results of the analysis showed no major increase in productions of Pinter's plays staged in Slovenia. However, we found that Pinter's Nobel Prize as well as his death each triggered a major media response, which significantly influenced the reception of his plays and their popularity. The reviews, for example, were more positively oriented, giving praise to Pinter and his work; they were longer and also more glowing, regardless of whether the performance of the play was good or bad. Moreover, events were organised that were solely dedicated to Pinter, 
for example, the project Pinter Abroad: Other Stages Other Rooms in 2011 (see Onič 2012). The vast development in technology and easier media accessibility could be considered reasons behind the larger number of articles and news previews referring to Pinter. They were longer and more frequent in many cases, since the amount of text in the electronic media is not directly connected to material cost, as in print, and is often less limiting in this respect.

In the conclusion of this subdivision, some statistical data comparing the periods before and after 1999 will be given. There were six Pinter plays performed in Slovenia before 1999 and eight after 1999. In the 31 years before 1999, there were 13 performances of Pinter's plays in Slovenia altogether. After 1999 this number increased to 14 in the last 15 years, which is a significant increase. The Pinter plays with the most productions in Slovenia before 2014 are The Dumb Waiter (5 productions) and The Birthday Party (5 productions), followed by Old Times (4 productions), Homecoming (3 productions) and Betrayal (3 productions). If we list the performances according to number, we can see that Betrayal was performed most often, followed by The Birthday Party and Homecoming. All this considered, it could be claimed that Pinter's popularity in Slovenia has increased since 1999.

\section{Pinter in the Slovene Intercultural Context}

This brief overview of Harold Pinter's plays on the Slovene stage shows that introducing this playwright to the Slovene audience was a lengthy process. If lack of insight into Pinter's significant style represented a reception obstacle to the British public and critics, it comes as no surprise that the process took longer in the culturally different and considerably closed communist/postcommunist Slovene environment. Gradually, the public began to appreciate Pinter's dialogue, with utterances full of recurrences, interruptions, hesitations, incomplete syntax, silences, pauses and other typical features of Pinter's style. ${ }^{7}$ The reviews of productions mounted after 1999 (and particularly after the Nobel Prize Award in 2005) began to treat his plays, without exception, as masterpieces. Thus, the reviewers moved from predominantly critiquing Pinter's style to mainly explaining it in their reviews, sometimes including their own interpretation of the play; eventually they reached the stage of praising the plays and commenting on the translations and the performances. Nowadays, the reviewers are familiar with Pinter's style; they embrace the fact that the interpretation should be left to each individual and mark a performance as marked as good if it raises more questions than answers; yet, his plays are still occasionally seen as complex and hard to understand. In the reviews before 1999, it often happened that the actors and the performance received praise, but the play itself was marked as worthless for the repertory or insufficiently engaging for the audience. Contrary to this, in the reviews after 1999 and particularly after 2005, the plays are always much appreciated, regardless of the performance quality.

Apart from the cultural differences that undoubtedly exist between the British and the Slovene literary and theatre spaces, the Slovene audience also faces the fact of translation. The critics as well as the academic researchers have recently identified this as one factor that often hampered the audience's perception of this new stream in drama. Particularly in the post-1999 commentaries, the translation quality is frequently recognized as crucial for the reception of the plays, while in early reviews this issue is almost never addressed. Hribar and Onič even report attempts in early translations to 'mend' the play in an explanatory way 'so that the reviewers

For more information on recurrences, in Pinter and generally, see Onič (2005b), Zlatnar Moe (2005), Zupan (2006); for a full account on Pinter's stylistic features, see Onič (2016). 
and the audience would understand it'. Such translators, obviously, failed to realize that Pinter had already mastered and "captured all the feelings, psychological states, moods, intentions and secrets with the power of words" $(2011,13)$. The translators must overcome the fear of possible misinterpretation, since, according to Pinter himself, this does not exist.

It is well known today that translating Pinter represents a particular challenge, since the translator must know the playwright's style well in order to be able to transfer its effects into the target context. Any unawareness in the phase of reading the original, or interventions or superficiality in the translation process may affect the interpretive potential of the text. As Onič (2005a) suggests in his study about preserving register in translation, any unawareness in the phase of reading the original, or interventions or superficiality in the translation process may affect the interpretive potential of the text. According to Meta Grosman $(1997,26)$, the translator can only translate the meaning $\mathrm{s} / \mathrm{he}$ created in his/her own reading of the original, while all other potential meanings are inevitably lost. It would, of course, be naïve to expect that a good translation can secure a quality production by itself, but it is obviously vital. Possibly, under the influence of reviews referring to this issue as well as academic studies addressing the importance of a good translation, four new translations of Pinter's plays appeared after 1999: The Birthday Party in 2002 by Zdravko Duša, Homecoming, staged in 2008, by Darja Dominkuš and The Dumb Waiter, staged in 2011, by Tomaž Onič; the new play, Celebration, was translated by Alja Predan. ${ }^{8}$ Judging by the reviews of the plays with new translations, these were better, fresh and improved.

Many reviewers used to believe that Pinter's plays were hard to understand and made no sense because the original scenery was placed in Britain, and Slovenes were therefore unable to identify with the concept of a big city or British humour. ${ }^{9}$ In the more recent performances of Pinter's plays in Slovenia, the settings are placed in the present, or possibly even an indefinite time, and are independent of place. Their ability to function in any place and any time indicates that the cultural gap has diminished, probably owing to globalization, modernization and media accessibility.

\section{Conclusion}

The reviewers seemed to be expecting more from the productions of Pinter's plays, so the experience of performance companies with staging Pinter as well as the knowledge of his style have become the norm rather than a bonus. In the reviews and with the audience, Pinter's reputation remains intact, independently of the performance quality. The latter mostly coincides with positive media response, which is evident from the fact that successful performances receive many awards, attract a lot of media attention and consequently also numerous playgoers and replays.

Comparing the reception of Pinter before 1999 and after, we can claim that a notable rise in awareness regarding his works and thus his popularity exists in this century. A few new, fresh and improved translations have brought Harold Pinter's plays closer to the public. In addition, there are several Slovene equivalents for the term 'Pinteresque' in the current vocabulary, and their use has become more frequent, which is another indication that Pinter's style has been successfully integrated into the Slovene cultural awareness. The number of reviews with definitions of Pinter's

Entire translations are available either in book format, Duša (2006); or in the relevant Theatre Programmes: Dominkuš (2008), Predan (2003), Onič (2011a).

9 A study on humour in Pinter and its translation into Slovene was published by Onič (2003). It includes multiple examples from The Caretaker. 
style and suggested interpretations has decreased. Instead, suggestions for individual initiative to find personalized interpretations of the plays has emerged, with a strong awareness that a good Pinter performance should give more questions than answers. As Darja Hribar puts it, "Forcing us to find our own interpretations of his characters' behaviour and reactions, the dramatist exerts trust in our judgements and capabilities, thus allowing different interpretations of human condition - an aim which is the core of Pinter's view on complexity of life" (Hribar 2004, 206). By comparing the situation before and after 1999, we can observe that there has been a considerable increase in Pinter plays staged per year since 1999. The constant presence of Pinter's plays on the Slovene theatre scene since 1967 proves that this playwright and his style have been successfully integrated in the Slovene theatre repertory. The awareness that we still can identify with the relationships and situations on Pinter's stage, even though decades have passed since some of these plays were written, suggests that Pinter's work is timeless and can become permanently harmonized into a non-British background.

\section{References}

Cave, Richard Allen. 2009. “Body Language in Pinter's Plays.” In The Cambridge Companion to Harold Pinter, edited by Peter Raby, 123-45. Cambridge: CUP.

Derbyshire, Harry. 2009. "Pinter as Celebrity." In The Cambridge Companion to Harold Pinter, edited by Peter Raby, 105-20. Cambridge: CUP.

Dominkuš, Darja. 2008. Vrnitev domov. In Theatre Programme of Slovene National Theatre in Ljubljana, n.p. Ljubljana: SNG.

Duša, Zdravko. 2006. Zabava za rojstni dan. In Zabava za rojstni dan in kratka proza, 7-106 Ivančna Gorica: Didakta.

Golob, Anja. 2004. "Instant magdalenica." Večer, January 31.

Goodspeed, Andrew. 2012. "The Dignity of Man': Pinter, Politics, and the Nobel Speech." ELOPE IX (Spring): 51-61. doi:10.4312/elope.9.1.51-61.

Grosman, Meta. 1997. "Književni prevod kot oblika medkulturnega posredovanja leposlovja." In Književni prevod, edited by Meta Grosman and Uroš Mozetič, 11-56. Ljubljana: Znanstveni inštitut Filozofske fakultete.

Hribar, Darja. 1999. Sestavine sloga Harolda Pinterja v slovenskih prevodih: vpliv slogovnih posebnosti na sprejemanje na Slovenskem. PhD diss., Univerza v Ljubljani.

-. 2004. "Harold Pinter in Slovene Translations." ELOPE 1 (1/2): 195-208. doi:10.4312/elope.1.1-2.195-208.

Hribar, Darja, and Tomaž Onič. 2011. “Slog - pomembna prevajalska kategorija pri prevajanju Pinterja.” In Mutasti natakar, Theatre Programme of Mestno gledališč Ptuj, edited by Ana Strelec Bombek, 12-13. Ptuj: MGP.

Javornik, Marjan. 1970. "Pinterjeva inačica.” Delo, Jun 16: 5.

Jesenko, Primož. 2001 “Ljubimec kot simptom.” Delo, November 14.

Jurca Tadel, Vesna. 2003. “Verzije življenja, takšne in drugačne.” Sodobnost 67: 258-67.

—. 2008. "Magellijeva vrnitev." Sodobnost 72: 304-11.

Mrčela, Mirko. 1999. Sprejemanje dramatike Harolda Pinterja na Slovenskem. MA Diss, University of Ljubljana. 
Onič, Tomaž. 2003. "Problematika prevajanja komičnega v dramskih besedilih, specifika iger Harolda Pinterja." Vestnik 37 (1/2): 391-405.

—. 2004. "Reviewer's Response to Pinter's The Caretaker." Acta neophilologica 37 (1/2): 87-94.

—. 2005a. "Ohranjanje registra v dramskem prevodu." Vestnik 39 (1/2): 271-81.

—. 2005b. "Translating Recurrences in Pinter's Plays." ELOPE 2 (1/2): 293-99. doi:10.4312/elope.2.1-2.293-299.

—. 2007. "From 'not funny enough' to the Nobel Prize." Philologia 5 (5): 111-19.

—. 2008a. "Pogovorni in narečni izrazi v slovenskih dramskih prevodih - soočanje s prevajalskimi zagatami." Jezikoslovni zapiski, 14(1): 139-50.

—. 2008b. "Priljubljen pri režiserjih in igralcih, manj pri publiki: Harold Pinter na slovenskih odrih." Delo, December 31.

—. 2011a. Mutasti natakar. In Mutasti natakar, Theatre Programme of Mestno gledališč Ptuj, edited by Ana Strelec Bombek, 19-39. Ptuj: MGP.

—. 2011b. "Prevajanje Mutastega natakarja na povabilo Mestnega gledališča Ptuj”. In Mutasti natakar, Theatre Programme of Mestno gledališč Ptuj, edited by Ana Strelec Bombek, 14-15. Ptuj: MGP.

—. 2012. "Perspectives on Pinter Abroad." ELOPE IX (Spring): 5-9. doi:10.4312/elope.9.1.5-9.

—. 2014. "Early Productions of Pinter on the Slovene Stage." In Harold Pinter on International Stages, edited by Tomaž Onič, 77-87, Frankfurt am Main: Peter Lang.

—. 2016. “Slogovne značilnosti ... [premolk] ... Pinterjevega dialoga.” Primerjalna književnost, 39/2: 191208.

Predan, Alja. 2003. Praznovanje. In Theatre Programme of Mestno gledališč ljubljansko, n.p. Ljubljana: MGL.

Raby, Peter. 2009. Introduction to The Cambridge Companion to Harold Pinter, 2nd ed., edited by Peter Raby, 1-4. Cambridge: CUP.

Rak, Peter. 2011a. "Nedomišljeno in površno." Delo, March 31.

—. 2011b. “Dobri Stari časi.” Delo, May 31.

Ravnjak, Marjana. 2006. Review of The Dumb Waiter performance from TV Slovenija, November 27. Accessed June 20, 2014. http://www.mladinsko.com/predstave/arhiv-predstav/jasek/kritike/.

SiGledal, portal slovenskega gledališča. 2015. Accessed March 10. http://www.veza.sigledal.org/.

Svetej, Dario. 2001. "V družbi plačanih morilcev.” Večer, March 10.

Štaudohar, Irena. 2013. "Harold Pinter, tisti, ki ni nikoli pisal o sreči.” Delo, September 27.

Tadel, Boštjan. 2011. "Dobri igralci brez režiserja.” Pogledi, October 26.

Wardle, Irwing. 1958. Comedy of Menace. Encore 5: 28-33.

Zlatnar Moe, Marija. 2005. “(Ne)ponavljanje blizu skupaj stoječih prvin v književnih prevodih.” Vestnik, 39 (1/2): 187-204.

Zupan, Simon. 2006. "Repetition and translation shifts." ELOPE 3 (1/2): 257-68. doi:10.4312/elope.3.1-2.257-268. 